\title{
Development of a Molecular Tool for the Diagnosis of Leprosis, a Major Threat to Citrus Production in the Americas
}

\author{
Eliane Cristina Locali, Centro APTA Citros 'Sylvio Moreira'/IAC, Rod. Anhanguera Km 158, CP 4, 13490-970, \\ Cordeirópolis-SP, Brazil; Juliana Freitas-Astua and Alessandra Alves de Souza, Centro APTA Citros 'Sylvio \\ Moreira'/IAC, Rod. Anhanguera Km 158, CP 4, 13490-970, Cordeirópolis-SP, Brazil, and Empresa Brasileira de \\ Pesquisa Agropecuária; Marco Aurélio Takita, Gustavo Astua-Monge, and Renata Antonioli, Centro APTA \\ Citros 'Sylvio Moreira'/IAC, Rod. Anhanguera Km 158, CP 4, 13490-970, Cordeirópolis-SP, Brazil; Elliot W. Ki- \\ tajima, Depto. Entomol., Fitopatol. \& Zool. Agríc., Escola Superior de Agricultura 'Luiz de Queiroz', Universidade \\ de São Paulo, CP 9, 13418-900, Piracicaba, SP, Brazil; and Marcos Antonio Machado, Centro APTA Citros 'Syl- \\ vio Moreira'/IAC, Rod. Anhanguera Km 158, CP 4, 13490-970, Cordeirópolis-SP, Brazil
}

\begin{abstract}
Locali, E. C., Freitas-Astua, J., de Souza, A. A., Takita, M. A., Astua-Monge, G., Antonioli, R., Kitajima, E. W., and Machado, M. A. 2003. Development of a molecular tool for the diagnosis of leprosis, a major threat to citrus production in the Americas. Plant Dis. 87:1317-1321.

Citrus leprosis virus (CiLV), a tentative member of the Rhabdoviridae family, affects citrus trees in Brazil, where it is transmitted by mites Brevipalpus spp. It also occurs in other South American countries and was recently identified in Central America. This northbound spread of CiLV is being considered a serious threat to the citrus industry of the United States. However, despite its importance, difficulties related to the biology of CiLV have hindered much of the progress regarding its accurate detection, leaving both the analyses of symptoms and electron microscopy as the only tools available. An attempt to overcome this problem was made by constructing a cDNA library from double-stranded RNA extracted from leprosis lesions of infected Citrus sinensis (sweet orange) leaves. After cloning and sequencing, specific primers were designed to amplify putative CiLV genome regions with similarity to genes encoding the movement protein and replicase of other plant viruses. RNA from infected citrus plants corresponding to different varieties and locations were amplified by reverse transcriptionpolymerase chain reaction (RT-PCR) using the two pairs of primers. Amplified products were purified, cloned in pGEM-T, and sequenced. The sequences confirmed the genomic regions previously associated with CiLV. The results demonstrate that RT-PCR was specific, accurate, rapid, and reliable for the detection of CiLV.
\end{abstract}

Additional keywords: Brevipalpus sp., citrus diseases, Citrus leprosis virus, RT-PCR

Leprosis, a disease caused by Citrus leprosis virus (CiLV) and transmitted by the false spider mite Brevipalpus spp. (Acari: Tenuipalpidae), is considered as an unassigned member of the Rhabdoviridae family because of its bacilliform, rhabdoviruslike morphology $(7,15)$. So far, three species, B. phoenicis (Geijskes), B. californicus (Banks), and B. obovatus Donnadieu, have been demonstrated to vector citrus leprosis $(14,18,28)$. Infected plants show localized chlorotic lesions commonly with necrotic rings in the leaves, depressed chlorotic or brownish lesions in the fruits, and lesions in the bark of the stems. Affected leaves and fruits may drop prematurely. Heavy infection can lead eventually to the death of the tree $(4,9)$. The virus can

Corresponding author: M. A. Machado

E-mail: marcos@centrodecitricultura.br

Accepted for publication 30 May 2003.

Publication no. D-2003-0829-02R

(C) 2003 The American Phytopathological Society mite vector, or the examination of tissue sections of lesions by transmission electron microscopy since the virus causes characteristic cytopathic effects in the cytoplasm or nucleus of infected cells $(4,7,9,12$, unpublished). Because CiLV virions accumulate in distinct places in infected cells, it has been proposed that there are two types of CiLV: the cytoplasmic and the nuclear types (E. W. Kitajima, C. M. Chagas, and J. C. V. Rodrigues, unpublished). The analysis of symptoms is not always reliable since they could be confused with those caused by other citrus pathogens, especially citrus canker and zonate chlorosis $(21,22)$. In addition, appearance of lesions after mite transmission assays may take months, and electron microscopy is timeconsuming, limited to the analyses of a small number of samples, and requires expensive facilities (7).

The increasing importance of citrus leprosis, however, has led to the search for more efficient methods for the accurate diagnosis of this disease. Purification of CiLV has been very difficult due to the low concentration and the lability of the particles, precluding the production of antiserum for immunological assays. Colariccio et al. (6) and Rodrigues et al. (20) reported double-stranded RNAs (dsRNAs) associated with CiLV-infected citrus leaves, but could not confirm that the dsRNA bands observed in agarose gels indeed corresponded to CiLV. In this manuscript, we report the construction of a doublestranded RNA (dsRNA) based cDNA library and the development of reverse transcription-polymerase chain reaction (RTPCR) tools for CiLV detection.

\section{MATERIALS AND METHODS}

Construction of the cDNA library and primer design. $d s R N A$ isolation for the construction of the cDNA library. Leaves of sweet orange var. Pêra exhibiting symptoms of citrus leprosis were collected from a plant from Cordeirópolis, SP, and rinsed with water. Two grams of isolated lesions were powdered in liquid nitrogen using a mortar and pestle. Double-stranded RNA was extracted using the CF-11 column 
method, according to Valverde et al. (27). After the extraction, dsRNA was digested with Mung bean nuclease (Gibco BRL, Gaithersburg, MD) and DNase I-RNase free (Boehringer Mannheim, Mannheim, Germany) enzymes, following the manufacturers' instructions. An aliquot was visualized in a $1 \%$ agarose gel containing ethidium bromide at $0.5 \mu \mathrm{g} / \mathrm{ml}$.

cDNA library construction and sequencing. CiLV dsRNA bands were extracted from low melting point (LMP) gel and used as template for the cDNA library. Around $100 \mathrm{ng}$ of purified dsRNA was denatured at $95^{\circ} \mathrm{C}$ for $10 \mathrm{~min}$. Synthesis of the first cDNA strand was performed using SuperScript (Invitrogen, San Diego, CA) and genome-directed primers (GDPs). GDPs were designed based on the genomic sequences of members of Nucleorhabdovirus and Cytorhabdovirus genera available in the GenBank database as described by Talaat et al. (25). The GDPs based on the reverse sequences of rhabdoviruses are: Rhabdo 1, TTTTCTTA; Rhabdo 2,
TGCCTCTG; Rhabdo 3, TCTTTGAT; Rhabdo 4, TGATTGAT; Rhabdo 5, AATTTGAT; Rhabdo 6, AGATATCC; Rhabdo 7, TATATATT; Rhabdo 8, TGATGCCA; Rhabdo 9, TCTTCTCC; Rhabdo 10, CCTTTGTC; Rhabdo 11, TCTAAGTA; Rhabdo 12, TATCTGAT; Rhabdo 13, GACATCAT; Rhabdo 14, TCTTTAAT; Rhabdo 15, CAGGCATT; Rhabdo 16, TGTCTCT; and Rhabdo 17, GACAAATA.

The second cDNA strand was synthesized from the first-strand template using DNA polymerase I enzyme (Promega Co., Madison, WI) according to the manufacturer's instructions. The product was extracted with phenol:chloroform and precipitated with ethanol and $3 \mathrm{M}$ sodium acetate. It was then ligated to adapters and amplified by nested PCR following the Bacterial Genome Subtraction Kit - Clontech PCR - select kit (Clontech, Palo Alto, CA) protocol with few modifications. For the ligation to the adapters, a mix was made with $5 \mu \mathrm{l}$ of purified second-strand

Table 1. Results of RT-PCR amplifications ${ }^{\mathrm{a}}$ and cytopathological analyses of citrus leprosis diseased leaf collections

\begin{tabular}{|c|c|c|c|c|c|c|}
\hline \multirow[b]{2}{*}{ Plant species } & \multirow[b]{2}{*}{ Variety } & \multirow{2}{*}{$\begin{array}{c}\text { No. of } \\
\text { samples }\end{array}$} & \multirow[b]{2}{*}{ Origin } & \multicolumn{2}{|c|}{ RT-PCR ampl. } & \multirow[b]{2}{*}{ Cytop. $^{b}$} \\
\hline & & & & MP & Rep & \\
\hline \multirow[t]{31}{*}{ Citrus sinensis } & Pêra & 6 & Cordeirópolis-SPc & $6 / 6$ & $6 / 6$ & n.e. \\
\hline & Pêra & 1 & Borborema-SP & $1 / 1$ & $1 / 1$ & n.e. \\
\hline & Pêra & 14 & Piracicaba-SP & $14 / 14$ & $14 / 14$ & + \\
\hline & Lima & 1 & Piracicaba-SP & $1 / 1$ & $1 / 1$ & + \\
\hline & Lima verde & 1 & Piracicaba-SP & $1 / 1$ & $1 / 1$ & n.e. \\
\hline & Pêra Rio & 1 & Corumbataí-SP & $1 / 1$ & $1 / 1$ & n.e. \\
\hline & Pêra Rio & 1 & Duartina-SP & $1 / 1$ & $1 / 1$ & n.e. \\
\hline & Pêra Rio & 1 & Olímpia-SP & $1 / 1$ & $0 / 1$ & n.e. \\
\hline & Pêra Rio & 1 & Paraguaçu Paulista-SP & $1 / 1$ & $1 / 1$ & - \\
\hline & Pêra Rio & 1 & Piracicaba-SP & $1 / 1$ & $1 / 1$ & n.e. \\
\hline & Pêra Rio & 3 & Sta. Cruz do Rio Pardo-SP & $3 / 3$ & $3 / 3$ & $2+1-$ \\
\hline & Pêra Rio & 1 & Taiuva-SP & $1 / 1$ & $0 / 1$ & + \\
\hline & Pêra Rio & 1 & Ubarana-SP & $1 / 1$ & $1 / 1$ & + \\
\hline & Pêra Rio & 1 & Ubirajara-SP & $1 / 1$ & $1 / 1$ & - \\
\hline & Pêra Rio & 1 & Vera Cruz-SP & $1 / 1$ & $1 / 1$ & + \\
\hline & Natal & 1 & Borborema-SP & $1 / 1$ & $1 / 1$ & - \\
\hline & Natal & 1 & Cafelândia-SP & $1 / 1$ & $1 / 1$ & n.e. \\
\hline & Natal & 2 & Colômbia-SP & $2 / 2$ & $1 / 2$ & - \\
\hline & Natal & 1 & Cosmorama-SP & $1 / 1$ & $1 / 1$ & + \\
\hline & Natal & 1 & Frutal-MG & $1 / 1$ & $1 / 1$ & n.e. \\
\hline & Natal & 1 & Piracicaba-SP & $1 / 1$ & $1 / 1$ & n.e. \\
\hline & Natal & 1 & Ubarana-SP & $1 / 1$ & $1 / 1$ & + \\
\hline & Hamlin & 1 & Monte Azul Paulista-SP & $1 / 1$ & $0 / 1$ & + \\
\hline & Hamlin & 1 & Piracicaba-SP & $1 / 1$ & $1 / 1$ & n.e. \\
\hline & Seleta & 1 & Piracicaba-SP & $1 / 1$ & $1 / 1$ & n.e. \\
\hline & Barão & 1 & Piracicaba-SP & $1 / 1$ & $1 / 1$ & n.e. \\
\hline & Valencia & 2 & Borborema-SP & $2 / 2$ & $2 / 2$ & + \\
\hline & Valencia & 1 & Cafelândia-SP & $1 / 1$ & $1 / 1$ & n.e. \\
\hline & Valencia & 1 & Piracicaba-SP & $1 / 1$ & $1 / 1$ & + \\
\hline & $\begin{array}{l}\text { Valencia Folha } \\
\text { Murcha }\end{array}$ & 1 & Boa Esperança do Sul-SP & $1 / 1$ & $1 / 1$ & n.e. \\
\hline & Bahia & 1 & Piracicaba-SP & $1 / 1$ & $1 / 1$ & n.e. \\
\hline \multirow[t]{4}{*}{ C. reshni } & Cleopatra & 6 & Cordeirópolis-SP & $6 / 6$ & $6 / 6$ & + \\
\hline & Cleopatra & 1 & $\begin{array}{l}\text { Marechal Cândido Ron- } \\
\text { don-PR }\end{array}$ & $1 / 1$ & $1 / 1$ & + \\
\hline & Cleopatra & 1 & Piracicaba-SP & $1 / 1$ & $1 / 1$ & n.e. \\
\hline & - & 2 & Campinas-SP & $2 / 2$ & $2 / 2$ & n.e. \\
\hline C. aurantifolia & Sweet lime & 1 & Piracicaba-SP & $1 / 1$ & $1 / 1$ & n.e. \\
\hline C. reticulata & Ponkan & 1 & Borborema-SP & $1 / 1$ & $1 / 1$ & + \\
\hline
\end{tabular}

${ }^{a}$ Reverse transcription-polymerase chain reaction amplification.

${ }^{\mathrm{b}}$ Cytopathology: n.e., not examined; presence (+) or absence (-) of cytopathic effects associated with Citrus leprosis virus infection.

${ }^{c}$ SP, São Paulo State; MG, Minas Gerais State; PR, Paraná State;-, unknown variety.
cDNA, $2 \mu \mathrm{l}$ of $5 \times$ ligation buffer, $2 \mu \mathrm{l}$ of the adapter 1 (5'- CTAATACGACTCATAGGGCTCGAGCGGCCGCCCGGGCAGGT-3'), and $1 \mu \mathrm{l}$ of T4 DNA ligase 400 $\mathrm{U} / \mu \mathrm{l}$. After $16 \mathrm{~h}$ incubation at $16^{\circ} \mathrm{C}, 1 \mu \mathrm{l}$ of EDTA $0.2 \mathrm{M}$ was added to the reaction, which was then incubated at $72^{\circ} \mathrm{C}$ for 5 min for enzyme inactivation. Three microliters of the cDNA ligated to the adapter 1 , $2.5 \mu \mathrm{l}$ of PCR $10 \times$ buffer, $1.25 \mu \mathrm{l}$ of $\mathrm{MgCl}_{2}$ $50 \mathrm{mM}, 1 \mu \mathrm{l}$ of nested primer $1\left(5^{\prime}-\right.$ TCGAGCGGCCGCCCGGGCAGGT-3'), $0.5 \mu \mathrm{l}$ of $10 \mathrm{mM}$ dNTPs, $1 \mu \mathrm{l}$ of Taq DNA polymerase, and $15.75 \mu \mathrm{l}$ Milli-Q $\mathrm{H}_{2} \mathrm{O}$ were mixed in the first amplification reaction. The PCR program consisted of 1 cycle at $72^{\circ} \mathrm{C}$ for $10 \mathrm{~min}, 1$ cycle at $94^{\circ} \mathrm{C}$ for $10 \mathrm{~min}, 35$ cycles at $94^{\circ} \mathrm{C}$ for $1 \mathrm{~min}$, $66^{\circ} \mathrm{C}$ for $30 \mathrm{~s}, 72^{\circ} \mathrm{C}$ for $90 \mathrm{~s}$.

The product of the first round of PCR was diluted 10 -fold, and $5 \mu \mathrm{l}$ of it was used as template for the second reaction, which was performed exactly as described above. PCR products were purified from a $0.8 \%$ LMP gel with the QIAquick Extraction kit (QIAGEN Inc., Valencia, CA) and used for cloning after quantification in a $1 \%$ agarose gel. Ten microliters of the purified PCR product, $1 \mu \mathrm{l}$ of pGEM-T $(50 \mathrm{ng} / \mu \mathrm{l}$; Promega), $1.3 \mu \mathrm{l}$ of $10 \times$ ligation buffer, and $1 \mu \mathrm{l}$ of T4 DNA ligase were used in the ligation reaction. The reaction was incubated for $16 \mathrm{~h}$ at $4{ }^{\circ} \mathrm{C}$. After the ligation was completed, $13.3 \mu$ of the reaction was used to transform $50 \mu$ l of Escherichia coli DH5 $\alpha$ competent cells. The inserts carried by the recombinant clones were sequenced in automatic sequencer ABI Prism 3700 (Applied Biosystems, Foster City, CA).

Computer analysis. Sequences obtained were analyzed using the Sequencing Analysis Program from Perkin Elmer, Seq Man Lasergene 99 (DNASTAR Inc., Madison, WI). Sequences were also analyzed with Phred, Phap, and Consed using a quality threshold of 300 bases with Phred quality greater than 20. Sequences were assembled with the program CAP3 (11). Sequences corresponding to the adapters and vector used for cloning were trimmed off and discarded before the analyses.

Analyses of CiLV genomic regions and primers design. DNA sequences corresponding to the contigs and singletons obtained in the assembly were compared to the nonredundant GenBank database using the BLASTX and BLASTN algorithms (1). Sequences with homology to known viral genes were used to design primers using the Primer select software, part of the package Lasergene 99 (DNASTAR), and the Primer3 program (24). Primers designed for the genomic region corresponding to the CiLV putative movement protein gene $(M P)$ were named MPF: $5^{\prime}$ GCGTATTGGCGTTGGATTTCTGAC-3' and MPR: 5'-TGTATACCAAGCCGCCTGTGAACT-3', and those designed for the genomic region corresponding to the putative replicase gene (Rep) were named 
RepF: 5'-GATACGGGACGCATAACA3' and RepR: 5'-TTCTGGCTCAACATCTGG-3'.

Evaluation of RT-PCR diagnostic tools. Total RNA was extracted from 50 to $100 \mathrm{mg}$ of fresh healthy or symptomatic leaf tissues from 70 citrus test samples as described by Gibbs and Mackenzie (10). Test samples were ground in liquid nitrogen, and $500 \mu \mathrm{l}$ of wash buffer $(10 \mathrm{mM}$ Tris-HCl, pH 8.0, 1 mM EDTA, pH 8.0, 2 $\mathrm{M} \mathrm{NaCl}, 0.05 \%$ bovine serum albumin [BSA]) was added. After vortex mixing and centrifugation at maximum speed for 5 min, $600 \mu$ l of extraction buffer $(2 \%$ CTAB [hexadecyltrimethylammonium bromide], 1.4 M NaCl, 0.1 M Tris-HCl, $\mathrm{pH} 8.0,0.5 \%$ $\beta$-mercaptoethanol) was added to the pellet, vortex mixed, and incubated at $55^{\circ} \mathrm{C}$ for 15 to $30 \mathrm{~min}$. Samples were extracted with $400 \mu \mathrm{l}$ of phenol:chloroform:isoamyl alcohol (25:24:1), vortex mixed, and centrifuged at maximum speed for $5 \mathrm{~min}$. The aqueous phase was removed and mixed with $1 / 10$ of the volume of $7.5 \mathrm{M}$ ammonium acetate and 1 vol of isopropanol. The samples were incubated at $-20^{\circ} \mathrm{C}$ for $15 \mathrm{~min}$, centrifuged at maximum speed for $5 \mathrm{~min}$, and washed with $70 \%$ ethanol. The pellet was air-dried and resuspended in 20 to $30 \mu \mathrm{l}$ of diethyl pyrocarbonate (DEPC)-treated $\mathrm{H}_{2} \mathrm{O}$. RNA concentration and purity were estimated in a spectrophotometer or denaturing agarose gels (1\% agarose, $6.7 \%$ formaldehyde, morpholinepropanesulfonic acid [MOPS] 10x [200 mM morpholino-propanesulfonate, 5 $\mathrm{mM}$ sodium acetate, $10 \mathrm{mM}$ EDTA] and DEPC-treated $\mathrm{H}_{2} \mathrm{O}$ ). Samples were kept at $-80^{\circ} \mathrm{C}$. Total RNA from 400 viruliferous and 400 nonviruliferous mites were also extracted by the same protocol.

RT-PCR was performed using $1 \mu \mathrm{l} \mathrm{M}$ MLV-RT (Invitrogen), $1.5 \mu \mathrm{l}$ of $50 \mathrm{mM}$ $\mathrm{MgCl}_{2}, 5 \mu \mathrm{l}$ of total RNA, and $100 \mathrm{ng}$ of any of the following primers: random primers mix, oligo dT, or GDP mix (described above). Samples were denatured at $95^{\circ} \mathrm{C}$ for $10 \mathrm{~min}$ and put into ice. Then, 4 $\mu \mathrm{l}$ of $5 \times$ buffer were added along with $1 \mu \mathrm{l}$ of $10 \mathrm{mM}$ dNTP mix, $0.5 \mu \mathrm{l}$ of $2 \mathrm{mM}$ DTT, $1 \mu \mathrm{l}(15 \mathrm{U})$ of RNase inhibitor (RNasin Gibco BRL), $1 \mu \mathrm{l}$ (200 U) of M-MLV-RT (Invitrogen), and sterile Milli-Q water to a $20-\mu$ final volume. The reaction was incubated at $37^{\circ} \mathrm{C}$ for $2 \mathrm{~h}$.

All RT-PCR amplifications were conducted using a PTC 100 (MJ Research, Waltham, MA) thermocycler. The reactions consisted of $2.5 \mathrm{mM} \mathrm{MgCl} 2,10 \mathrm{mM}$ dNTP mix (Invitrogen), $100 \mathrm{ng}$ of each primer (MPF and R or RepF and R), $2 \mu \mathrm{l}$ of cDNA first strand used as template, 1.0 U of Taq DNA polymerase (Invitrogen), and sterile Milli-Q water for a final volume of $25 \mu \mathrm{l}$. An initial denaturation cycle at $94^{\circ} \mathrm{C}$ for 2 min was followed by 32 cycles of denaturation at $94^{\circ} \mathrm{C}$ for $30 \mathrm{~s}$, annealing at $56^{\circ} \mathrm{C}$ for $30 \mathrm{~s}$, and extension at $72^{\circ} \mathrm{C}$ for $40 \mathrm{~s}$. A final 5-min extension was added to the cycle. Eight microliters of the PCR product was run in a $1 \%$ agarose gel. Primers p20F (5'-ACAATATGCGAGCTTACTTTA-3') and p20R (5'-AACCTACACGCAAGATGGA-3'), designed by Rubio et al. (23) to amplify 575 bp within the p20 gene of Citrus tristeza virus (CTV), were used to detect the presence of this closterovirus in the samples. The conditions for PCR were the same as described above.

PCR specificity. In order to assess the specificity of the primers, 70 citrus plants were tested. Forty-six plants, exhibiting an array of symptoms typical of leprosis and corresponding to 14 varieties within four species of Citrus, were collected from 20 different locations, mainly in São Paulo State (Table 1). Fourteen healthy plants from sweet orange var. Pêra, and Cleopatra and Ponkan mandarins from Cordeirópolis, SP, and Piracicaba, SP, were used as negative controls. Ten citrus plants asymptomatic for CiLV but infected with CTV, an endemic virus in Brazil, were used in order to determine whether or not the primers designed against CiLV were specific for the leprosis virus. cDNA from groups of 400 viruliferous and 400 nonviruliferous mites were also tested by the designed primers.

cDNA cloning and sequencing. $10 \mu \mathrm{l}$ of each PCR product obtained with each pair of primers specific for the regions that apparently code for the CiLV MP and Rep proteins were LMP gel purified and ligated in pGEM-T (Promega Co.). Transformation of E. coli DH5 $\alpha$ competent cells and sequencing of the inserts were performed as previously described. Sequences were analyzed and compared to those available in the GenBank database.
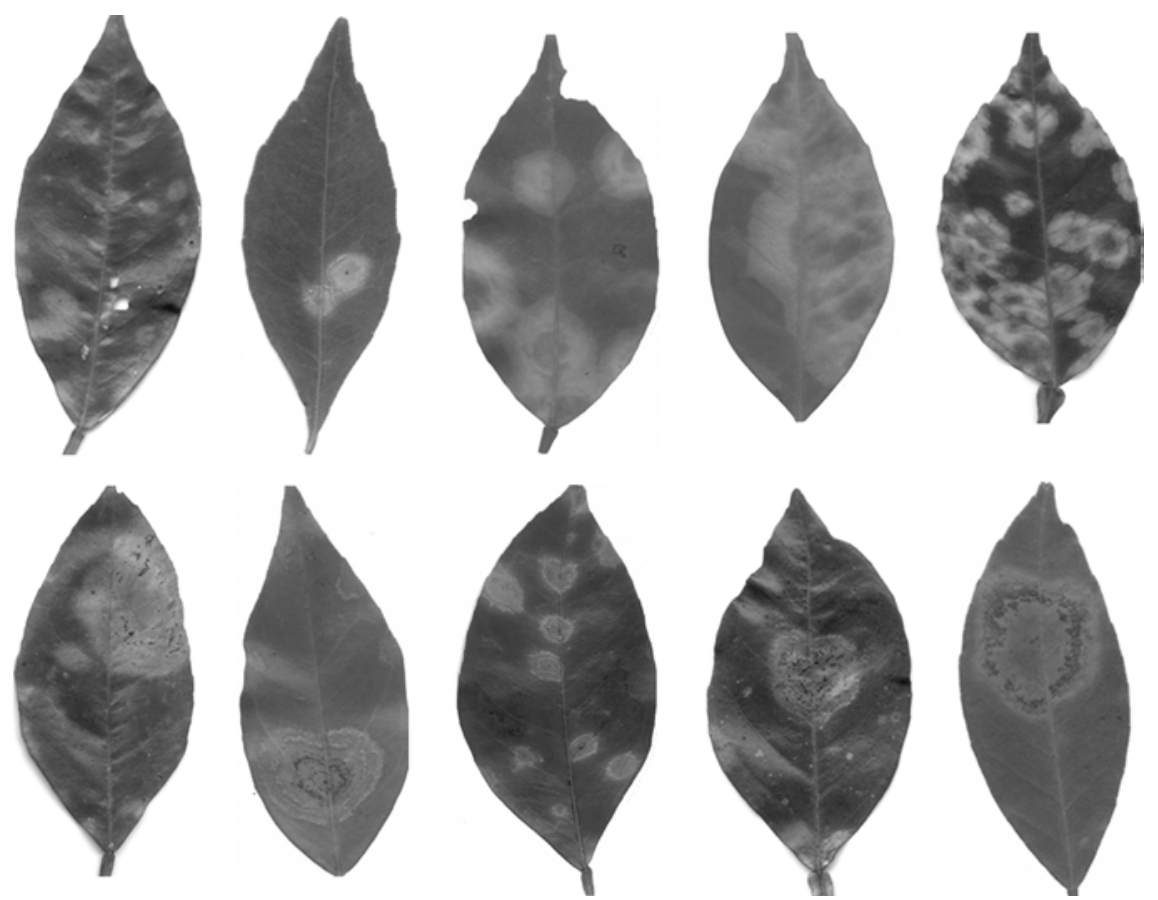

Fig. 1. Array of symptoms caused by Citrus leprosis virus in citrus leaves. Note the diversity of shapes, sizes, and tones.
Transmission electron microscopy. Most of the citrus samples bearing leprosis lesions analyzed by PCR were also examined as thin sections to correlate molecular and cytopathological detection. Small ferent of the leaf lesions (from three diffor thin section analyses as described elsewhere (13). Examinations were made with a Zeiss EM900 transmission electron microscope.

\section{RESULTS}

Sequence analyses. Sequences obtained from the CiLV cDNA libraries formed 27 contigs and 89 singletons. BLAST comparisons indicated that at least three of those contigs exhibited similarity to regions associated with genes found in other plant viruses. One of the contigs encoded a putative cell-to-cell movement protein (MP) (GenBank accession number AY289190) with sequence similarity to the MP of furoviruses, such as Sorghum chlorotic spot virus (SrCSV). The translated sequences of CiLV and SrCSV
(GenBank accession number NP 659021) shared $22 \%$ identity (54/239 amino acids), $46 \%$ positives (110/239 amino acids), and gave and expected e-value of $10^{-8}$. Two additional contigs encoded non-overlapping fragments of a putative Rep proAY289191) accession number those found in members of the genera $\mathrm{Fu}$ rovirus, Hordeivirus, Tobravirus, and Tobamovirus. The translated putative Rep region sequences of CiLV and the furovirus Oat golden stripe virus (OGSV; GenBank accession number NP_059510.1) had $23 \%$ identity (69/290 amino acids), 38\% 
positives (113/290 amino acids), and expected e-value of $10^{-7}$.

Symptom analyses. Lesions observed in infected citrus leaves exhibited a large array of sizes, varying from 2 to several millimeters in diameter. Lesion shapes varied from well-defined circles to more elliptical spots, mainly when lesions were close to the leaf veins. The colors of the lesions ranged from pale to bright yellow, with or without green halo in the center. Necrotic ring spots within and around circular lesions were also observed in some cases (Fig. 1).

PCR specificity. Regardless of the variability of the symptoms and the primer used for cDNA synthesis (GDP, random, or oligo dT), all tested samples exhibiting leprosis symptoms were positive when MP primers were used (Table 1). Amplimers of $339 \mathrm{bp}$ were observed in agarose gels for all symptomatic samples (Fig. 2A). When the Rep primers were used, all but four symptomatic samples tested positive and exhibited the expected 402-bp product after electrophoresis (Fig. 2B, Table 1). Cloning and sequencing of the PCR products obtained with both primer pairs con- firmed that the amplimers had sequence identity to the putative sequences previously identified as regions of the CiLV genome. None of the samples asymptomatic for leprosis, including CTV-positive samples, was amplified with the specific CiLV primers. All CTV-positive plants were amplified with the CTV primers (Fig. 3 ). Only the viruliferous mite samples were amplified by the CiLV primers, while the nonviruliferous mites did not produce an RT-PCR product (data not shown).

Electron microscopy. In most of the examined samples, cytopathic effect of the cytoplasm type (dense viroplasm in the cytoplasm and short, bacilliform, membrane-bounded particles in the cisternae of endoplasmic reticulum) was found (Table 1).

\section{DISCUSSION}

This study reports the development of the first specific, molecular diagnostic tool for the detection of cytoplasmic-type CiLV. We demonstrated that through a cDNA library constructed from viral dsRNA template, it was possible to identify putative genomic regions of CiLV that exhibited

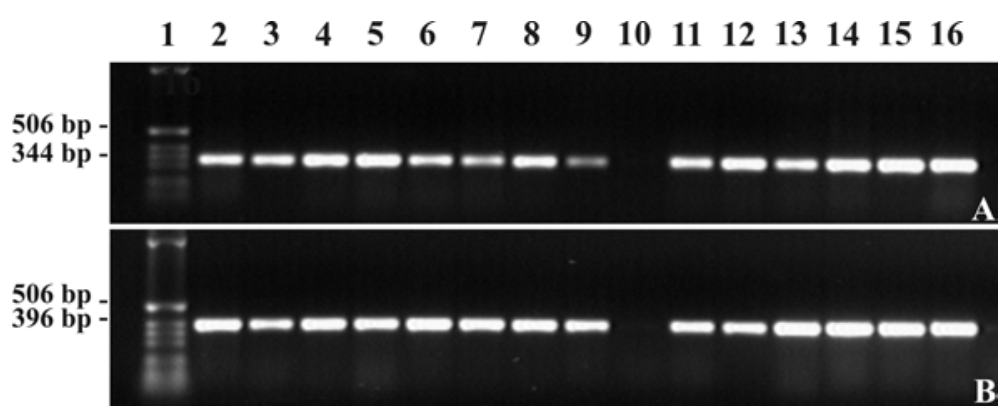

Fig. 2. Agarose-gel electrophoresis of reverse transcription-polymerase chain reaction (RT-PCR) products obtained from different citrus varieties and origins exhibiting symptoms of Citrus leprosis virus (CiLV) using two CiLV-specific primers. A, Using MP primers, B, Using Rep primers. Lane 1: 1-kb extension ladder (Gibco); 2: Pêra from Cordeirópolis; 3: Pêra from Piracicaba; 4: Pêra Rio from Paraguaçu Paulista; 5: Pêra Rio from Santa Cruz do Rio Pardo; 6: Natal from Cafelândia; 7: Natal from Frutal; 8: Natal from Ubarana; 9: Hamlin from Piracicaba; 10: Pêra from Piracicaba (asymptomatic, negative control); 11: Valencia from Borborema; 12: Valencia from Cafelândia; 13: Valencia Folha Murcha from Boa Esperança do Sul; 14: Cleopatra from Cordeirópolis; 15: Cleopatra from Marechal Candido Rondon; 16: Ponkan from Borborema.

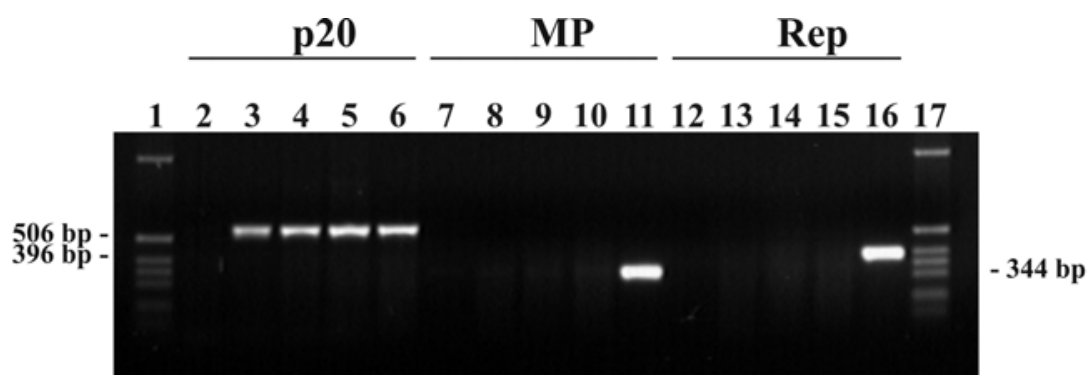

Fig. 3. Agarose-gel electrophoresis of reverse transcription-polymerase chain reaction (RT-PCR) products obtained from leprosis asymptomatic, Citrus tristeza virus (CTV)-infected citrus plants using primers p20 (specific for CTV): lanes 2 to 6; MP (specific for Citrus leprosis virus [CiLV]): lanes 7 to 11; Rep (specific for CiLV): lanes 12 to 16. Lanes 1 and 17: 1-kb extension ladder (Gibco); lanes 2, 7, and 12: Pêra free of CiLV and CTV from Cordeirópolis; lanes 3, 8, and 13: CTVinfected, CiLV-free Poncirus trifoliata $\times$ Citrus sunki hybrid from Codeirópolis, plant 1; lanes 4, 9, and 14: CTV-infected, CiLV-free P. trifoliata $\times$ C. sunki hybrid from Codeirópolis, plant 2; lanes 5, 10, and 15: CTV-infected, CiLV-free P. trifoliata $\times$ C. sunki hybrid from Codeirópolis, plant 3; lanes 6, 11, and 16: CTV- and CiLV-infected Pêra from Cordeirópolis. similarity to $M P$ and Rep genes from different plant viruses. However, the sequence information derived from our study did not permit us yet to draw conclusions about the taxonomic position of the CiLV due to some degree of conservation of the Rep protein from a diverse group of viruses, i.e., furoviruses, hordeiviruses, tobraviruses, and tobamoviruses, among others (26). In addition, the similarities found between CiLV and other plant viruses were relatively low and cannot be considered conclusive.

The RT-PCR assay developed in this study, especially using the MP primers, has proven to be an efficient, rapid, and reproducible method for the detection of CiLV, regardless of the type of symptoms observed in the sampled leaves. In addition, the specificity of the test is very high even in the presence of other viruses such as CTV. Compared to electron microscopy, PCR assays revealed a higher sensitivity to detect CiLV. Overall, 15 of 19 samples positive for CiLV by RT-PCR were confirmed by electron microscopy (Table 1). This was presumably due to processing a larger amount of tissue to overcome uneven distribution of virus in the lesions contrasted to the very small volume of tissue observed by electron microscopy. The fact that four samples from the same geographic region were amplified by the MP, but not by the Rep primers, suggests that genetic variation exists among isolates of CiLV in Brazil. Hence, we recommend the use of both primers to minimize false negatives and guarantee the efficiency and reliability of assays performed. Based on the high specificity and reproducibility of the PCR-based assay, it is ideal for diagnosis, epidemiology, quarantine regulations, certification programs, and breeding programs.

\section{ACKNOWLEDGMENTS}

We thank R. B. Bassanezi from Fundecitrus, N. L. Nogueira from Centro de Energia Nuclear na Agricultura (CENA/USP), and J. C. V. Rodrigues from the Citrus Res. \& Ed. Ctr. of the University of Florida (CREC/UF) for providing infected citrus samples. We also thank L. Kishi from CAPTACSM for his assistance with the computer analyses. This research was partially supported by Fundação de Amparo à Pesquisa do Estado de São Paulo (FAPESP). E.C.L. was supported by a fellowship from Fundação de Apoio à Pesquisa Agrícola (FUNDAG). M.A.T., G.A.M, and R.A were supported by fellowships from FAPESP.

\section{LITERATURE CITED}

1. Altschul, S. F., Madden, T. L., Schaffer, A. A. Zhang, J., Zhang, Z., Miller, W., and Barret, A. J. 1997. Gapped BLAST and PSI-BLAST: A new generation of protein database search programs. Nucleic Acid Res. 25:3389-3402.

2. Araya Gonzáles, J. 2000. Informe sobre la prospección de la "leprosis de los cítricos" en la zona fronteriza sur (Costa Rica - Panamá). Ministerio Agricultura Ganadería.

3. Bassanezi, R. B., Spósito, M. B., and Yakamoto, P. T. 2002. Adeus à leprose. Revista Cultivar, 10 ed.

4. Bitancourt, A. A. 1955. Estudos sobre a leprose dos citros III - Transmissão natural às 
frutas. Arq. Instit. Biológ. 22:205-218.

5. Childers, C. C., Kitajima, E. W., Welbourn, W. C., Rivera, C., and Ochoa, R. 2001. Brevipalpus mites on citrus and their status as vectors of citrus leprosis. Manejo Integrado Plagas 60:66-70.

6. Colariccio, A., Lovisolo, O., Boccardo, G., Chagas, C. M., D'aquilio, M., and Rossetti, V. 2000. Preliminary Purification and Double Stranded RNA Analysis of Citrus Leprosis Virus. 14th IOCV Conf. pp. 159-163.

7. Colariccio, A., Lovisolo, O., Chagas, C. M., Galetti, S. R., Rossetti, V., and Kitajima, E. W. 1995. Mechanical transmission and ultrastructural aspects of citrus leprosis virus. Fitopatol. Bras. 20:208-213.

8. Dominguez, F. S., Bernal, A., Childers, C. C., and Kitajima, E. W. 2001. First report of Citrus leprosis virus in Panama. Plant Dis. 85:228.

9. Fawcett, H. S. 1936. Citrus diseases and their control. McGraw-Hill Book Co., New York.

10. Gibbs, A., and Mackenzie, A. 1997. A primer pair for amplifying part of the genome of all potyvirids by RT-PCR. J. Virol. Methods 63:9-16.

11. Huang, X., and Madan, A. 1999. CAP3: A DNA sequence assembly program. Genome Res. 9:868-877.

12. Kitajima, E. W., Muller, G. W., Costa, A. S., and Yuki, V. A. 1972. Short, rod-like particles associated with citrus leprosis. Virology 50:254-258.

13. Kitajima, E. W., and Nome, C. 1999. Micro- scopia electronica en virologia vegetal. Pages 59-87 in: Métodos para detectar patógenos sistémicos. D. DoCampo and S. Lenardon, eds. Córdoba, INTA/IFFIVE

14. Knorr, L. C. 1968. Studies on the etiology of leprosis in citrus. Proc. IOCV Conf. 4:332341.

15. Lovisolo, O. 2001. Citrus leprosis virus: Properties, diagnosis, agro-ecology and phytosanitary importance. OEPP/EPPO Bull. 31:79-89.

16. Mejia, L., Paniagua, A., Cruz, N., Porras, M., and Palmieri, M. 2002. Leprosis de los cítricos, enfermedad que amenaza plantaciones en Guatemala. 42a Reunión Sociedad Americana Fitopatol.: 69.

17. Murayama, D., Agrawal, H. O., Inoue, T., Kimura, I., Shikata, E., Tomaru, K., Tsuchizaki, T., and Triharso, eds. 1998. Plant viruses in Asia. Bulasksumur, Gadjah Mada University Press.

18. Musumecci, M. R., and Rossetti, V. 1963. Transmissão dos sintomas da leprose pelo ácaro Brevipalpus phoenicis. Ciência Cultura $15: 228$.

19. Rodrigues, J. C. V., Nogueira, N. L., Muller, G. W., and Machado, M. A. 2000. Yield losses associated to citrus leprosis on sweet-orange varieties. Page 151 in: Int. Soc. Citricult. Congr., Orlando, FL.

20. Rodrigues, J. C. V., Targon, M. L. N., and Machado, M. A. 2000. dsRNA associado a lesões de leprose dos citros. Fitopatol. Bras. 25:447-448.
21. Rossetti, V. 1980. Diferenciação entre cancro cítrico e outras doenças. Citrus 1:23-26.

22. Rossetti, V., Nakadaiara, J. T., Calza, R., and Miranda, C. A. B. 1965. A propagação da clorose zonada dos citros pelo ácaro Brevipalpus phoenicis. O Biológico 31:113-116.

23. Rubio, L., Ayllón, M. A., Kong, P., Fernández, A., Polek, M., Guerri, J., Moreno, P., and Falk, B. W. 2001. Genetic variation of Citrus tristeza virus isolates from California and Spain: Evidence for mixed infections and recombination. J. Virol. 75:8054-8062.

24. Rozen, S., and Skaletsky, H. J. 2000. Primer3 on the WWW for general users and for biologist programmers. Pages 365-386 in: Bioinformatics Methods and Protocols: Methods in Molecular Biology. S. Krawetz and S. Misener, eds. Humana Press, Totowa, NJ.

25. Talaat, A. M., Hunter, P., and Johnston, S. A. 2000. Genome-directed primers for selective labeling of bacterial transcripts for DNA microarray analysis. Nature Biotechnol. 18:679 682.

26. Torrance, L. 2002. ICTVdb - The International Committee on Taxonomy of Viruses Database. Genus Furovirus. ICTV. Published online.

27. Valverde, R. A., Nameth, S. T., and Jordan, R L. 1990. Analysis of double-stranded RNA for plant virus diagnosis. Plant Dis. 74:255-258

28. Vergani, A. R. 1945. Transmisión y naturalez de la "lepra explosiva del naranjo". (Publ.) Min. Agric. Nacion. B. Aires Inst. Sanid Veg., 3, 11 p. 